A N N A L E S

UN IVER S T ATIS M A R I E C URIE-SKŁODOW S A

LUBLIN - POLONIA

VOL. XXXIII, 4

SECTIO J

2020

Maria Curie-Skłodowska University in Lublin. Faculty of Pedagogy and Psychology

\title{
MAŁGORZATA OSIŃSKA
}

ORCID: 0000-0002-0609-2327, osinska.malgorzata79@gmail.com

\section{Personal Resources of Convicts Functioning in Penitentiary and Non-custodial Social Rehabilitation Systems}

Zasoby osobiste skazanych funkcjonujących w systemie resocjalizacji zakładowej i wolnościowej

How to QUOTE THIS PAPER: Osińska, M. (2020). Personal Resources of Convicts Functioning in Penitentiary and Non-custodial Social Rehabilitation Systems. Annales Universitatis Mariae Curie-Sktodowska. Sectio J, Paedagogia-Psychologia, 33(4), 113-132. DOI: https://doi.org/10.17951/j.2020.33.4.113-132.

\section{ABSTRACT}

The purpose of this article is to compare personal resources of convicts serving the penalties in penitentiary isolation and those under the supervision of probation officers. The tests measuring selfefficacy, self-esteem, stress-coping, perceptual social support and ego resiliency have been employed to examine sixty-six convicts and sixty-eight supervised individuals. Contrary to expectations, the convicted are characterised by the fairly high level of most of the examined resources. At the same time, both groups proved to be so similar that statistically significant differences were revealed only as regards the level of self-esteem, cognitive support and strategies for coping with stress in the form of use of psychoactive substances. Positive correlations between the examined variables have been confirmed, and the analyses were supplemented by the structure of the subjective resources being studied in both groups. The paper presents limitations and directions for further research.

Keywords: social support; self-esteem; sense of self-efficacy; ego resiliency; stress coping; delinquency; personal resources

\section{INTRODUCTION}

Penitentiary and non-custodial social rehabilitations are the processes aimed at not only making the convicts aware of the harmfulness of their former behaviour, but primarily at providing them with the skills that protect them against the repeated infringement of law. Appropriate social adjustment requires possessing a personal potential (personal resources) and the capabilities for using it on the 
part of the convicts (Jaworska, 2016). The resources have a regulatory impact on human's behaviour (Machel, 2003) and play a moderating and mediating role in re-socialisation. Findings from numerous studies confirm that implementation of correctional purposes requires producing changes in the convicts' personality structures, which should determine commencement of adequate interactions with respect to them. Thus, a thorough diagnosis of the broadly understood life situation of the convicts, along with their personal potential, is highly necessary (Bałandynowicz, 2016; Niewiadomska, 2010). In the context of effectiveness of social rehabilitation, the initiation of interactions directed towards accomplishment of convicts' moral improvement is more and more frequently postulated, which entails reaching the maximum purpose (Machel, 2003). It is important to take into account the fact that it should refer to all the persons covered by social rehabilitation interactions both the persons deprived of liberty and the perpetrators of the offenses remaining under the supervision of probation officers. Recognition of subjective resources is the prerequisite for planning adequate interactions and increasing the chances for the achievement of changes in a much broader context than just refraining oneself from the repeated commitment of the offense (Niewiadomska, 2010). The authors of works pertaining to the mentioned issue draw attention to a significant role of personality factors in social adjustment, which is inextricably linked with the possibilities of introducing the desirable changes. Of particular relevance are especially these subjective resources that engage the convicts into the work on overcoming difficulties, they are as follows: self-esteem level (Kieszkowska, 2012; Niewiadomska, 2010), a sense of self-efficacy (Juczyński, 2000; Łaguna, 2015; Niewiadomska 2010), perceptual social support (Niewiadomska, 2010), effective coping with stress (Ogińska-Bulik, 2008; Rode, 2010; Niewiadomska, 2010), ego resiliency (Ogińska-Bulik, 2008; Borys, 2010; Ostaszewski, 2008).

Self-esteem is one of the most significant structural aspects of "self", constituting also the predictor for formulating a coherent self-concept. The effects of self-esteem are visible in the fundamental areas of human functioning, i.e. in the task-based dimension, in the social dimension as well as in the one concerning self-image and feeling of the quality of life. It is one of the most crucial regulators of human behaviour (Łaguna, Lachowicz-Tabaczek, Dzwonkowska, 2007) determining internal and external functioning of an individual, which implies the capacity to integrate emotions, personal convictions, reactions to difficult situations and, consequently, it determines an individual's life activity - pro-developmental versus maladaptive (Huflejt-Łukasik, 2010).

The outcomes of the majority of studies regarding self-esteem of socially maladjusted persons point to a negative correlation between the two variables. The persons disclosing social maladjustment and committing offences are usually characterised by the larger discrepancy between the real "self", the ideal "self" and 
ought "self" and present a more negative image of themselves. Low self-esteem, developing itself in the adolescent period, obstructs motivation for action (Ostrihanska, 1978). New research suggests, however, that both low and high self-esteem correlates with social maladjustment, whereas its average level corresponds with a proper adjustment (Eaguna, et al., 2007). On top of that, a higher level of social maladjustment, the indicator of which is the infringement of legal norms, relates to a more negative image of "self" and lowered self-esteem (Wysocka, Ostafińska-Molik, 2014). Inadequately low level of self-esteem causes that a human being avoids taking on difficult tasks and, in the situation of misfortune, displays a greater tendency for self-destructive behaviours and the behaviours that are non-compliant with social and legal norms, the examples of which are: use of psychoactive substances, risky sexual behaviours, aggression, or criminal activity (Puskar, Bernardo, Haley, et al., 2010; Jaworska, 2016).

Another subjective resource important to social adjustment is a sense of self-efficacy (Bandura, 2001), referring to the beliefs of an individual about the possibility to perform the tasks undertaken by him, and the achievement of the results planned despite of the existing obstacles (Ogińska-Bulik, Juczyński, 2008). Research findings prove that it positively correlates with proper adjustment (Bandura, 2001), deferred gratification, focus on a task, self-confidence, motivation and persistence in actions, use of constructive stress coping strategies in stressful situations (Tomczak, 2009), and the capacity to take advantage of the support in difficult situations (Landis, Altman, Cavin, 2007). It constitutes a variable differentiating functioning of individuals in cognitive, motivational, emotional and behavioural spheres (Juczyński, 2000). Low level of self-efficacy is connected with the increase of sense of helplessness, weaker orientation in one's own situation and resignation from the designated purposes (Kościelak, 2010; Bańka, 2016). The analyses of studies pertaining to the persons in penitentiary isolation reveal a low level of one's own self-efficacy in this particular group (Belniak, 2014), which is related to perceiving one's own situation as a failure and is yet strengthened by the feeling of monotony and lack of real impact on situation as well as by absence of the closest persons (Niewiadomska, Chwaszcz, 2010). The convicts are characterised by wishful thinking, formulation of rather unreal goals and lack of involvement in its realisation (Steuden, Jaworowska, 2004). It is worth highlighting that lower sense of self-efficacy is attributable to repeat penitentiary offenders, whereas higher level to the persons placed in penal institutions for the first time. Studies also prove that the higher the level of one's self-efficacy, the lower the risk of the repeated infringement of public order (Benda, 2001). Meanwhile, the persons actively engaged in criminal activity, declaring satisfaction from such a way of life and deriving substantial financial benefits from the unlawful activity are characterised by high level of self-efficacy. In addition, the specified and established way of functioning 
causes that they are resistant to social rehabilitation interactions (Brezina, Topalli, 2012).

A significant subjective resource is also represented by ego resiliency, implying the ability of both proper social functioning and handling fate adversities in spite of objective difficulties. It is the property of an individual associated with adaptive flexibility, expressed in the capacity to control the level of impulses according to the existing situation (Letzring, Block, Funder, 2005; Kaczmarek, Sęk, Ziarko, 2011). High level of resiliency affects all the spheres of human functioning connected with social adjustment. An essential component in its development consists in social support, both the external one in the form of a support network (family, school, friends) and the perceptual one. Research confirms that ego resiliency is a crucial component of the mechanism of invoking positive emotions in stressful situations and departure from traumatic experiences. Positive emotions are intertwined with the processes influencing an individual's good health condition, which is connected with an overall level of mental well-being (Fredrickson, Tugade, Waugh, et al., 2003). The persons with low level of ego resiliency and low control over impulses more frequently encounter difficulties in adjusting reaction to the existing situation, they distinguish themselves by emotional rigidity and high amplitude of the experienced emotions, in addition to difficulties with deferring gratification. Due to inadequate functioning, it is conducive to the violation of norms and may give rise to social rejection or, on the contrary, due to spontaneous behaviours, it may boost interpersonal attraction (Kaczmarek, Sęk, Ziarko, 2011). Low level of resiliency contributes to maladjustment of an individual and may be prognostic for its further functioning. Studies conducted on the persons threatened with exclusion show correspondence between higher level of ego resiliency and lower escalation of negative emotions. It was proved that there is a positive correlation between this variable and social support (Szwajca, 2014), which leads to this resource being of paramount importance in the process of re-socialisation (Jaworska, 2016; Kwadrans, Konaszewski, 2018; Kieszkowska, 2012).

Support is a cognitive structure relating to the possibilities of receiving assistance in difficult and stressful situations as perceived by an individual. The conviction as to the scope of the gaining support arises as a result of the assistance received in the past and in the presence (Dudek, Koniarek, 2003), but it is of a prospective nature, because it refers to situations which may, but do not have to, occur (cf. Hobfoll, 2006). Research pertaining to social support shows that the perceived support rather than the received one is much more significant in the adjustment to new situation and stress coping. It also profoundly influences an individual's mental and physical health (Juczyński, 2000; Niewiadomska, 2010). In addition, it has been shown that the perceptual social support has larger predictive properties as regards mental and health well-being, coping with stress and stressful events, rather than the received social support (Mashi, 2007). Its level is 
connected with an individual's previous experience of obtaining support in difficult situations and it decisively corresponds with the effectiveness of the process of re-socialisation, in particular of the persons placed in penal institutions whose support level decreases (Kieszkowska, 2012; Jaworska, 2016; Niewiadomska, Chwaszcz, 2010). The persons having sense of bond with a close relative and actively functioning in social relationships present a higher level of perceptual social support. Studies also reflect a moderating role of the social support in future criminal activity. The analyses conducted among a group of young men aged 12-17, threatened with violence and stressful events of high intensity, point to a vital role of support in minimising the likelihood of committing brutal punishable acts in the future (Maschi, 2007). Therefore, it is so essential in the social rehabilitation process to organise real support for the convicts so as to prevent their being alienated or left to themselves (Bałandynowicz, 2016). More importantly, empirical analyses confirm the link between lack of support and return to offense (Kieszkowska, 2012; Niewiadomska, 2010).

In the context of social adjustment, the necessity of strengthening the ability to cope with difficult and stressful situations is frequently mentioned. Stress exerts a sustained impact on human being and disturbs the feeling of internal balance. It results in the necessity to take adequate preventive measures by an individual, aimed at restoration of the harmony between the things it can live up and the things it actually goes through. These measures are referred to as "coping" and are recognised under the three possible categories: process, strategy, or style (Terelak, 2008).

In the literature one can find a number of classifications of styles and remediation strategies (Terelak, 2008). Nonetheless, regardless of the concept, the primary goal of coping consists in its effectiveness (Heszen-Niejodek, 2000). There are no research results unequivocally determining which strategies are effective, and which are not, because it is conditional upon a single situation.

In case of the persons infringing legal norms and socially maladjusted, it is essential to recognise their ways of coping with difficult situations as it has influence on the process of re-socialisation (Niewiadomska, Chwaszcz, 2010; Belniak, 2014). These persons quite often make use of strategies inadequately to situation, which is not conducive to their proper functioning. The use of ineffective strategies may exacerbate maladjustment, increase the anxiety level, depression, and lead to aggression and delinquency (Seiffge-Krenke, 2000). It is confirmed by the studies conducted in the home country by Kieszkowska among a group of persons serving isolation penalties. The convicts participating in studies took advantage of emotional and task styles. The escalation of emotional style was associated with impulsive actions and provoking conflicts in freedom (Kieszkowska, 2012). Similar results were obtained by Niewiadomska and Chwaszcz (2010) who examined the convicts, the persons who left penal institutions, and juveniles. The conclu- 
sion can be made therefrom that the emphasis should be put on the development of constructive strategies of coping with difficult situations, as it is a relevant factor in counteracting criminal career. The studies proved the assumptions that the effectiveness of remediation strategies has an impact on social adjustment and depends on both personal qualities and situation.

The aim of this article is to analyse levels of subjective resources and correlations between them in two groups: the group of convicts serving the penalty of deprivation of liberty in the closed institutions and the persons remaining under the supervision of probation officers. The indicated personal variables are of paramount importance for social adjustment and re-socialisation, which is confirmed by the research. It is worth noticing that the expected changes in the functioning of convicts are not exclusively the resultant of interactions undertaken by institutions, but they are also linked to personal potential of the convicts, their motivation and the need to introduce positive changes, plus their personal situation. Recognition of resources and its strengthening in the process of social rehabilitation is highly significant since it serves as the basis for formulating individual interactions plans (Fidelus, 2012). Meanwhile, the account should be taken of the fact that these are the persons staying in penitentiary isolation that are most frequently subject to research. The comparison of both groups will enable us to verify if the persons remaining in the conditions of the supervised freedom actually differ from the convicts remaining in penal institutions in terms of a personal potential.

The following research questions were posed:

1. What is the level of personal resources (self-esteem, perceptual social support, a sense of self-efficacy, coping with stress, ego resiliency) of the studied convicts?

2. Do the studied persons remaining in the penitentiary unit and in non-detention settings differ as regards possessed personal resources?

3. Are there any correlations between the selected personal resources of the examined convicts?

Based on the analysis of previous studies, which are relatively scarce, with respect to studying the persons under the supervision of probation officers, the following hypotheses were put forward:

1. The studied convicts remaining in the conditions of penitentiary isolation are to be characterised by lower level of personal resources as compared to the studied individuals in non-detention settings (Jaworska, 2016; Kieszkowska, 2012; Konaszewski, Kwadrans, 2018; Niewiadomska, 2010; Niewiadomska, Chwaszcz, 2010).

2. It is to be expected that moderately positive correlations are to appear among the personal resources (Łaguna, et al., 2007; Judge, 2009, Niewiadomska, Chwaszcz, 2010, Warnecke, et al., 2014). 


\section{AUTHOR'S OWN RESEARCH}

The research comprised both groups. The first group encompassed men committed to Penal Institution in Zamość city and the second group the men remaining under the supervision of probation officers in the Regional Court Lublin-East in Lublin with its registered office in Świdnik and in the Regional Court LublinWest in Lublin. After prior notification of the aim of studies, its anonymous (in case of the penal institution) and confidential (in case of the supervised persons) nature and voluntary participation, the consent for participation was given by 77 convicted persons (eventually 66 persons completed questionnaires) and 185 persons ${ }^{1}$, both women and men remaining under the supervision of probation officers. For further analyses, as part of the research, a group of 68 men (the supervised ones) was chosen, and combined with a group of convicts, with account taken of age and similar socio-economic situation. The assumption of such a combination consisted in obtaining research groups of similar qualities.

\section{CHARACTERISTICS OF RESEARCH PARTICIPANTS}

The most numerous group among research participants was composed of the young persons between the ages of 20 and 39 (PI 42 persons $-63.6 \%$, SV 43 persons $-63.2 \%)^{2}$. The average age was similar in both groups: PI -35.94 $(\mathrm{SD}=11.975), \mathrm{SV}-35,66(\mathrm{SD}=11.208)$. In both groups there were persons aged over 60 years (PI -3 persons $-4.5 \%, \mathrm{SV}-4.4 \%$ ), which points to a low percentage of the convicted individuals in this age.

The analysis of socio-economic data shows that both groups reflect specification of the population of the convicted individuals. The majority of them are persons with basic and vocational education (PI $-36.4 \%$, SV $-49.8 \%$ ) of fairly unstable professional and financial situation, which is confirmed by the data pertaining to employment, sources of income and work experience. No statistically significant differences have been observed among the groups in these respects. Instead, the groups differed in terms of family situation, though these differences were not so strongly marked $\left(\mathrm{Chi}^{2}=6.903, \mathrm{df}=1, \mathrm{p}<0.05, \mathrm{~V}=0.194\right)$. In the group of persons committed to penal institution there were substantially more single persons $(62.1 \%)$, which may point to the difficulties in stabilising their private life. In the group of the supervised persons, $54.5 \%$ of them declared the absence of a life partner. Meanwhile, research participants from both groups declared good family relationships (PI - 90.9\%, SV - 89.3\%). Such high scores may not, how-

\footnotetext{
A group of persons comprised by research as part of preparation of $\mathrm{PhD}$ dissertation.

2 [Translator's note: Whenever the abbreviations PI and SV are used, they mean Penal Institution and Supervision respectively]
} 
ever, reflect reality and suggest both lack of criticism and the ability to make a reflection.

The analyses relating to socio-economic variables and the variables characterising legal situation of research participants do not produce evidence for the existence of statistically significant differences between the groups. In the group of convicts (there were 60 respondents) over a half of them has been punished for the first time $(51.7 \%)$, the penalty has been undergoing for the first time by $89.4 \%$ of the convicts. Moreover, in the group of those punished and supervised, there was one time less of them $(31.3 \%)$.

\section{RESEARCH METHODOLOGY}

The following set of techniques, enabling measurement of the selected personal resources, and author's own survey were incorporated into the research in order to gather information relating to socio-economic situation:

1. Generalised Self-Efficacy Scale (GSES) by Schwarzer, Jeruzalem and Juczyński (2001),

2. Rosenberg's Self-Esteem Scale (SES) as adapted by Dzwonkowska, Lachowicz-Tabaczek and Łaguna (2008),

3. Interpersonal Support Evaluation List (ISEL) by Cohen and Hoberman in the Polish adaptation by Szlachta (2009),

4. Coping Inventory for Stressful Situations (the Mini-COPE) by Carver in the Polish adaptation of Juczyński and Ogińska-Bulik (2009),

5. Ego-Resiliency Scale (ERS) by Block and Kremen in the Polish adaptation of Kaczmarka (2011),

6. Author's own survey for the convicted persons, consisting of two parts, the aim of which was to gather and systematise information pertaining to the convicts engaged in research,

7. Questionnaire for the analysis of author's own documentation, which was used to gather and systematise the information contained in the documentation as prepared by probation officers in the duration of supervision.

8. Author's own questionnaires served as a source of information as regards social resources of research participants.

\section{SCORE ANALYSIS}

The performed analysis of the distribution of scores of the measured variables revealed quite satisfactory compliance with the normal distribution, which allowed to follow consecutive steps as regards statistical inference.

The analysis of general scores, whereas in the case of self-esteem and selfefficacy of the sten scores in the designated groups, revealed that the convicted 
persons have low level of self-esteem, and the supervised ones - the average level ( $\mathrm{PI}-\mathrm{M}=4.48 ; \mathrm{SV}-\mathrm{M}=5.18$ ), which is consistent with previous research findings. In contrast, as for self-efficacy (GSES), both groups present its high level, which is confirmed by average scores (PI $-\mathrm{M}=6.68$; $\mathrm{SV}-\mathrm{M}=6.51$ ). Interestingly, the convicts have a higher level of self-efficacy compared with the persons in non-detention settings. Moreover, high score of the indicated variable, as possessed by them, is in contrast with previous research reports, since it appears therefrom that the convicts remaining in penitentiary isolation, accompanied by the feeling of having no impact on reality, have low level of self-efficacy (Belniak, 2014). It is possible that this score stems from the distorted perception of one's own possibilities and/or inappropriate interpretation of incoming events (Steuden, Jaworowska, 2004).

The analysis of general scores with respect to coping with stress (see table 1) showed that the studied individuals from both groups obtained higher scores as regards coping methods treated as problem-focused strategies (Ogińska-Bulik, Juczyński, 2009), i.e. active coping, planning and search for instrumental support. On the other hand, lower scores were obtained in coping methods understood as emotion-oriented strategies (Ogińska-Bulik, Juczyński, 2009), i.e. search for emotional support, shift towards religion and contradiction. As part of the strategies treated as adjustable, i.e. positive overvaluation and acceptance, the scores were also high, with the higher level in the group of convicts, which is consistent with previous research findings, pointing to the use of strategies facilitating reconciliation with and adaptation to isolation conditions. Within the scope of performance of other activities strategy, known as less effective (Ogińska-Bulik, Juczyński, 2009), the scores were also relatively high, similarly as in the case of the self-blame strategy. With reference to other strategies (discharge, use of psychoactive substances, cessation of activities and a sense of humour) the studied individuals obtained lower scores.

The analysis of the perceptual social support (ISEL) disclosed that the studied individuals from both groups obtained average scores (see table 1). The obtained scores relating to ego resiliency (ERS), in turn, were high in both groups (table 1), which additionally suggests that the persons subject to research cope with difficult situations in their lives very well and they are able to control impulses. At the same time, the obtainment of such high scores by the studied individuals was incompatible with expectations (Kaczmarek, et al., 2011).

The next stage of the analysis consisted in the comparison of scores in both research groups so as to verify the hypothesis about the existence of statistically significant differences concerning the studied subjective resources between the groups. The obtained scores have been presented in table 1 . 
Table 1. Differences of average scores of SES, GSES, ISEL, Mini-Cope (M-C) and ERS in the compared groups

\begin{tabular}{|c|c|c|c|c|c|}
\hline Variables & Group & Mean & SD & $\begin{array}{c}\text { Student's } \\
\text { t-distribution }\end{array}$ & P-value \\
\hline \multirow{2}{*}{ SES (raw scores) } & PI & 27.25 & 4.68 & \multirow{2}{*}{-1.370} & \multirow{2}{*}{$0.01 *$} \\
\hline & SV & 28.58 & 6.35 & & \\
\hline \multirow{2}{*}{ GSES (raw scores) } & PI & 30.40 & 6.05 & \multirow{2}{*}{0.469} & \multirow{2}{*}{0.412} \\
\hline & SV & 29.92 & 5.84 & & \\
\hline \multirow{2}{*}{ Active coping (M-C) } & PI & 2.06 & 0.63 & \multirow{2}{*}{-1.098} & \multirow{2}{*}{0.349} \\
\hline & SV & 2.18 & 0.66 & & \\
\hline \multirow{2}{*}{ Planning (M-C) } & PI & 2.04 & 0.65 & \multirow{2}{*}{-1.117} & \multirow{2}{*}{0.614} \\
\hline & SV & 2.16 & 0.63 & & \\
\hline \multirow{2}{*}{ Positive overvaluation (M-C) } & PI & 1.86 & 0.62 & \multirow{2}{*}{0.961} & \multirow{2}{*}{0.208} \\
\hline & SV & 1.74 & 0.73 & & \\
\hline \multirow{2}{*}{ Acceptance (M-C) } & PI & 1.95 & 0.76 & \multirow{2}{*}{0.544} & \multirow{2}{*}{0.839} \\
\hline & SV & 1.87 & 0.76 & & \\
\hline \multirow{2}{*}{ Sense of humour (M-C) } & PI & 1.31 & 0.79 & \multirow{2}{*}{1.641} & \multirow{2}{*}{0.769} \\
\hline & SV & 1.08 & 0.82 & & \\
\hline \multirow{2}{*}{ Shift towards religion (M-C) } & PI & 1.36 & 1.03 & \multirow{2}{*}{2.596} & \multirow{2}{*}{0.170} \\
\hline & SV & 0.92 & 0.94 & & \\
\hline \multirow{2}{*}{$\begin{array}{l}\text { Search for emotional support } \\
\qquad(\mathrm{M}-\mathrm{C})\end{array}$} & PI & 1.81 & 0.67 & \multirow{2}{*}{-0.967} & \multirow{2}{*}{$0.060 \sim$} \\
\hline & SV & 1.93 & 0.79 & & \\
\hline \multirow{2}{*}{$\begin{array}{l}\text { Search for instrumental support } \\
\qquad(\mathrm{M}-\mathrm{C})\end{array}$} & PI & 1.77 & 0.76 & \multirow{2}{*}{-0.864} & 0492 \\
\hline & SV & 1.88 & 0.70 & & 0.492 \\
\hline Performance of other activities & PI & 1.73 & 0.74 & 0212 & 0414 \\
\hline$(\mathrm{M}-\mathrm{C})$ & SV & 1.71 & 0.82 & 0.215 & 0.414 \\
\hline Contradiction $(\mathrm{M} C \mathrm{C}$ & PI & 1.49 & 0.80 & 1812 & 0004 \\
\hline Contradiction (IV-C) & SV & 1.24 & 0.78 & 1.012 & 0.904 \\
\hline Discharoe (M_C) & PI & 1.47 & 0.77 & 0525 & 0742 \\
\hline 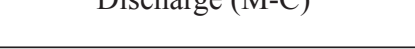 & SV & 1.40 & 0.82 & 0.020 & 0.142 \\
\hline Use of psychoactive substances & PI & 1.29 & 1.03 & 2316 & $0029 *$ \\
\hline$(\mathrm{M}-\mathrm{C})$ & SV & 0.90 & 0.88 & & \\
\hline Cecsation of activitios $(\mathrm{MC})$ & PI & 1.12 & 0.82 & 0732 & 0653 \\
\hline Cessationi or activities (IVI-C) & SV & 1.01 & 0.85 & 0.152 & 0.053 \\
\hline Self_blame (M_C) & PI & 1.73 & 0.83 & 1628 & 0309 \\
\hline 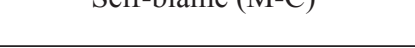 & SV & 1.51 & 0.78 & 1.020 & 0.507 \\
\hline Coonitive sunnort (ISFI) & PI & 26.74 & 2.71 & -3124 & $0051 *$ \\
\hline Cognituve support (ISEL) & SV & 25.41 & 2.87 & -5.124 & $0.051^{\circ}$ \\
\hline
\end{tabular}


Table 1. continued

\begin{tabular}{|c|c|c|c|c|c|}
\hline \multirow{2}{*}{ Financial support (ISEL) } & PI & 24.46 & 3.86 & \multirow{2}{*}{-3.012} & \multirow{2}{*}{0.098} \\
\cline { 2 - 4 } & SV & 25.39 & 2.92 & & \\
\hline \multirow{2}{*}{ Affiliation (ISEL) } & PI & 26.12 & 4.10 & \multirow{2}{*}{-0.420} & \multirow{2}{*}{$0.071 \sim$} \\
\cline { 2 - 4 } & SV & 26.38 & 3.02 & & \multirow{2}{*}{$0.055 \sim$} \\
\hline \multirow{2}{*}{ Appreciation (ISEL) } & PI & 23.36 & 3.91 & \multirow{2}{*}{-3.067} & \multirow{2}{*}{0.873} \\
\cline { 2 - 4 } & SV & 25.19 & 2.92 & \\
\hline \multirow{2}{*}{ Ego-Resiliency (ERS) } & PI & 40.36 & 7.94 & & \\
\cline { 2 - 4 } & SV & 40,63 & 7,52 & & \\
\hline
\end{tabular}

${ }^{*} \mathrm{p}<0,05 ; \mathrm{p}<0,074 \sim$

Source: own elaboration

The made analysis revealed significant differentiation of the groups' scores with respect to self-esteem level, cognitive support and one out of 14 strategies of coping with stress, i.e. the use of psychoactive substances strategy. In case of the strategy of searching for emotional support and the two dimensions of perceptual social support, i.e. affiliation and appreciation, the differences in level of statistical tendency occurred. The studied persons remaining under supervision have considerably higher level of self-esteem than the convicted persons, which in this particular case confirms the put forward hypothesis of higher level of subjective resources in the group associated with non-detention settings. Meanwhile, these are convicts who possess significantly higher level of cognitive support. This score is surprising because it shows that persons in penitentiary isolation have a greater sense of availability of support in the form of persons with whom they can discuss problems and receive feedback about the effectiveness of the activities undertaken by them (Szlachta, 2009). Perhaps it is really the outcome of a larger availability of such persons among fellow inmates and close relations as well as bonds established with them. In case of appreciation and affiliation, where statistical tendency occurred, these are the supervised persons who have a higher sense of acceptance and appreciation from the environment, in addition to the presence of important persons, with whom they may spend time and mutually undertake different activities (Szlachta, 2009). In the studied group the convicts significantly more often benefit from the strategy of coping with stress in the form of the use of psychoactive substances, whereas the supervised individuals more often benefit from the strategy of searching for emotional support.

With reference to the rest of the examined variables, there were no significant differences between the convicted persons and the supervised ones. It may suggest that the current living environment (prison isolation versus freedom) is not the factor differentiating socially maladjusted persons and the persons infringing legal norms. 
The next step consisted in discovering correlations between personal resources of the groups subject to research.

In both groups the analysis of correlations between the scores of the examined subjective resources has been performed with the use of Pearson's $r$ correlation coefficient. In the group of convicts significantly moderate correlation coefficients were obtained at the level of $0.31-0.42$ with $\mathrm{p}<0.01^{* *}$ and $\mathrm{p}<0.05^{*}$ between the scores of SES scale, measuring self-esteem, and GSES scale, measuring self-efficacy $\left(0.313^{*}\right)$, and yet between the SES scale and the following stresscoping strategies: performance of other activities $\left(-0.299^{*}\right)$, discharge $\left(-0.354^{* *}\right)$, use of psychoactive substances $\left(-0.374^{* *}\right)$, cessation of activities $\left(-0.425^{* *}\right)$ and self-blame (-0.370). There have not been found any other statistically significant correlations with self-esteem scores as regards the examined variables. The value of these coefficients is consistent with previous findings. It means that there is a moderate positive correlation between self-esteem and self-efficacy, and the correlation between self-esteem level and the use of evasive destructive strategies in the long term. In the group of supervised individuals, a moderate positive correlation between the scores of SES scale and self-efficacy has been obtained too $\left(0.477^{* *}\right)$. In case of the strategy of coping with difficult situations from among 14 its components moderate correlations were obtained solely with two of them, i.e. planning $(0.422 * *)$ and cessation of activities $(-0.308 *)$. On top of that, in the group of the supervised persons covered by research the scores of SES scale positively moderately correlated with ego resiliency, which was not true for the group of the convicted persons $\left(0.477^{* *}\right)$. A positive correlation between selfesteem and ego resiliency is consistent with previous research reports. Perhaps in the group of the convicted individuals it has not been noted on account of too low level of self-esteem scores. In fact, in the group of the supervised individuals, equipped with substantially higher level of this variable, this dependency has been revealed.

With regards to self-efficacy scale and a group of convicts, there have been noticed positive, moderate and strong correlations with active strategies of coping in difficult situations: active coping $\left(0.429^{* *}\right)$, planning $\left(0.514^{* *}\right)$, positive overvaluation $\left(0.392^{* *}\right)$, acceptance $\left(0.405^{* *}\right)$ and search for instrumental support $\left(0.313^{*}\right)$. In case of the strategy of searching for emotional support, the obtained correlation was positive but weak $(0.291 *)$. A slightly different distribution of dependencies was obtained in the group of supervised individuals subject to research. In this particular group the GSES scores the most strongly correlated with the planning strategy $\left(0.712^{* *}\right)$. Moderate correlations were discovered with such strategies as active coping $(0.362 * *)$ and search for emotional support $\left(0.399^{* *}\right)$, similarly as in the case of convicts. In the group of the supervised moderate and negative correlations with such strategies as the use of psychoactive substances $\left(-0.468^{* *}\right)$ and cessation of activities 
$(-0.429 * *)$ were obtained too, whereas positive and moderate correlations with the sense of humour $\left(0.336^{* *}\right)$. The scores confirm that the persons convinced about their self-efficacy believe that they are able to manage difficult situations, which is theoretically substantiated. However, in the case of the persons in liberty, it is clearly highlighted. In both research groups the highest correlation coefficient occurred between the GSES scale and ego resiliency measured by the ERS scale (PI $0.607^{* *}$; SV $0.698^{* *}$ ), which may be interpreted as the capacity of the persons with high self-efficacy level to control impulses, do not yield to adversities of fate, and return to balance after the experienced difficult situations.

In the area of ego resiliency, there have also been obtained positive moderate correlations with the problem-focused strategies of coping with stress, active and effective from the adaptation viewpoint (Juczyński, Ogińska-Bulik, 2009). It applied to both groups, but in the case of the supervised persons the correlations with a larger number of strategies were obtained, which may point to broader abilities of the group relating to the use of the repertoire of preventive activities. In the group of convicts the correlations with the following strategies were obtained: active coping $\left(0.414^{* *}\right)$, planning $\left(0.463^{* *}\right)$, acceptance $\left(0.431^{* *}\right)$, performance of other activities $\left(0.363^{* *}\right)$, whereas in the group of the supervised individuals: active coping $\left(0.358^{* *}\right)$, planning $\left(0.471^{* *}\right)$, positive overvaluation $\left(0.329^{* *}\right)$, search for emotional support $\left(0.546^{* *}\right)$, search for instrumental support $\left(0.366^{* *}\right)$, cessation of activities $\left(-0.405^{* *}\right)$ and self-blame $\left(-0.312^{* *}\right)$. The gathered results confirm previous research findings pertaining to the relationship between high level of ego resiliency and effective ways of dealing with difficult situations. In case of the perceptual social support, measured by the ISEL scale, in the group of convicts there was obtained a moderate, positive correlation with cognitive support and with the strategy of coping with difficult situations in the form of acceptance $\left(0.366^{* *}\right)$, appreciation, and shift towards religion $\left(0.353^{* *}\right)$. In the group of the supervised, there were correlations between the strategies of a sense of humour $\left(0.334^{* *}\right)$, discharge $\left(0.347^{* *}\right)$ and affiliations with the strategies of positive overvaluation $\left(0.387^{* *}\right)$ and acceptance $\left(0.343^{* *}\right)$.

For the purposes of deepening the research problem, the analyses were supplemented by exploratory factor analysis. It was aimed at establishing internal structure of the examined resources of both groups. The analysis was conducted with the application of principle component method and the Kaiser criterion. The account was taken of loading factors with the values exceeding 0.4 . In both research groups the analysis revealed that the structure of resources is made up of the three factors that in the case of convicts explain in total $51 \%$ of variances, while in the case of the supervised 53\% (table 2). 
Table 2. Values of loading factors of the analysed resources in the group of the studied convicts and the supervised individuals

\begin{tabular}{|c|c|c|c|c|c|c|}
\hline \multirow{2}{*}{ Variable } & \multicolumn{7}{|c|}{ Factors } \\
\cline { 2 - 7 } & \multicolumn{2}{|c|}{ Studied convicts } & \multicolumn{2}{l|}{ Studied supervised persons } \\
\cline { 2 - 7 } & I & II & III & I & II & III \\
\hline SES (raw scores) & 0.177 & $\mathbf{- 0 . 6 4 8}$ & 0.012 & $\mathbf{- 0 . 5 3 4}$ & 0.094 & -0.042 \\
\hline GSES (raw scores) & $\mathbf{0 . 6 5 2}$ & -0.225 & 0.196 & $\mathbf{- 0 . 7 1 6}$ & 0.288 & -0.021 \\
\hline Active coping (M-C) & $\mathbf{0 . 6 9 0}$ & -0.165 & 0.143 & $\mathbf{- 0 . 5 9 2}$ & 0.196 & 0.280 \\
\hline Planning (M-C) & $\mathbf{0 . 8 2 8}$ & -0.100 & 0.094 & $\mathbf{- 0 . 6 7 2}$ & 0.234 & 0.121 \\
\hline Positive overvaluation (M-C) & $\mathbf{0 . 5 2 1}$ & 0.157 & 0.402 & -0.050 & $\mathbf{0 . 7 1 1}$ & 0.096 \\
\hline Acceptance (M-C) & $\mathbf{0 . 6 4 6}$ & 0.107 & 0.060 & -0.095 & $\mathbf{0 . 7 1 3}$ & 0.169 \\
\hline Sense of humour (M-C) & 0.148 & 0.373 & -0.065 & 0.352 & 0.396 & -0.097 \\
\hline Shift towards religion (M-C) & $\mathbf{0 . 4 3 9}$ & 0.338 & -0.146 & $\mathbf{0 . 4 0 4}$ & 0.364 & -0.094 \\
\hline Search for emotional support (M-C) & $\mathbf{0 . 6 4 3}$ & -0.119 & 0.266 & -0.463 & $\mathbf{0 . 5 1 3}$ & 0.258 \\
\hline Search for instrumental support (M-C) & $\mathbf{0 . 5 9 8}$ & 0.145 & 0.192 & -0.275 & $\mathbf{0 . 6 3 8}$ & 0.163 \\
\hline Performance of other activities (M-C) & $\mathbf{0 . 4 1 6}$ & 0.374 & 0.047 & 0.156 & $\mathbf{0 . 6 0 4}$ & 0.479 \\
\hline Contradiction (M-C) & 0.030 & $\mathbf{0 . 4 7 9}$ & 0.209 & 0.449 & $\mathbf{0 . 4 9 9}$ & 0.428 \\
\hline Discharge (M-C) & 0.033 & $\mathbf{0 . 7 4 0}$ & 0.190 & $\mathbf{0 . 5 1 6}$ & 0.433 & 0.024 \\
\hline Use of psychoactive substances (M-C) & -0.127 & $\mathbf{0 . 7 6 9}$ & 0.165 & $\mathbf{0 . 6 5 8}$ & 0.083 & -0.136 \\
\hline Cessation of activities (M-C) & -0.289 & $\mathbf{0 . 7 2 9}$ & 0.034 & $\mathbf{0 . 7 7 9}$ & 0.155 & 0.140 \\
\hline Self-blame (M-C) & 0.097 & $\mathbf{0 . 6 2 9}$ & 0.373 & $\mathbf{0 . 5 4 4}$ & 0.215 & 0.397 \\
\hline Cognitive support (ISEL) & 0.490 & 0.384 & $\mathbf{0 . 6 4 3}$ & 0.061 & 0.430 & $\mathbf{- 0 . 6 5 9}$ \\
\hline Financial support (ISEL) & 0.371 & 0.390 & 0.311 & 0.132 & 0.399 & -0.378 \\
\hline Appreciation (ISEL) & 0.370 & 0.279 & $\mathbf{- 0 . 7 6 2}$ & 0.197 & $\mathbf{0 . 5 6 6}$ & -0.512 \\
\hline Affiliation (ISEL) & 0.283 & 0.225 & $\mathbf{- 0 . 7 4 7}$ & 0.153 & $\mathbf{0 . 5 8 7}$ & -0.575 \\
\hline Ego Resiliency (ERS) & $\mathbf{0 . 6 7 1}$ & -0.255 & 0.004 & $\mathbf{- 0 . 6 6 6}$ & 0.455 & -0.272 \\
\hline Percentage of the explained variances & 22.4 & 17.8 & 10.8 & 22.6 & 20.6 & 9.8 \\
\hline Souryyyyyy \\
\hline
\end{tabular}

Source: own elaboration

In the case of convicts, the first factor, accounting for $22.4 \%$ of variances, comprises a sense of self-efficacy, ego resiliency and the following stress-coping strategies: active coping, planning, positive overvaluation, acceptance, shift towards religion, search for emotional support, search for instrumental support and performance of other activities. The highest loading factors, among those mentioned above, are attributable to the strategy of active coping, ego resiliency and self-efficacy. This factor is loaded by the variables the high level of which determines proper adjustment and effective performance; hence it may be defined as active constructive. The second factor, accounting for $17.8 \%$ of variances, is loaded by self-esteem (with a negative loading) and the following stress-coping 
strategies: discharge, use of psychoactive substances, cessation of activities, selfblame, and contradiction. Due to a high factor loading of variables, having a negative correlation with adjustment, it may be defined as active destructive. As for the third factor, accounting for $10.8 \%$ of variances, there are three dimensions of social support with negative values. This is the factor expressing lack of support that may be defined as passive destructive.

As for the first factor, accounting for $22.6 \%$ of variances, in the research group under the supervision of a probation officer, a sense of self-efficacy, ego resiliency and self-esteem (with negative loadings) were discovered, in addition to the following stress-coping strategies: active coping, planning (with a positive loading), shift towards religion, discharge, use of psychoactive substances, cessation of activities and self-blame. In contrast to the first factor in the group of convicts, this factor is loaded by variables of a negative intensity expressing, on the one hand, helplessness, evasive behaviours and lack of resources so as to deal with difficulties and, on the other hand, emotional discharge as a consequence of helplessness. It is the active destructive factor. The second factor, in turn, accounting for $20.6 \%$ of variances, is loaded by: positive overvaluation, acceptance, search for instrumental support, search for emotional support, performance of other activities, contradiction, appreciation, affiliation and a sense of humour. This factor is expressed by the aspects pertaining to reconciliation with one's own situation and the aspects expressing evasive behaviours; hence this factor may be defined as acceptance and reconciliation. The third factor, which accounts for $9.8 \%$ of variances, is solely loaded by one of the aspects of the feeling of support, i.e. cognitive support. The cognitive support refers to availability of persons with whom an individual may discuss problems, thanks to which there is a greater chance of understanding the situation in which this individual actually occurs (Szlachta, 2009). This factor may be defined as search for support.

The three factors have been distinguished in each of the examined groups thanks to the factor analysis. In both groups active destructive factors were distinguished, however, in the group of the supervised it is the factor explaining the highest percentage of variances (the first factor), while in the group of convicts - it is the active constructive factor that is the first. The factor of such nature has not been distinguished in the group of the supervised individuals. Despite significant differences between the groups as regards the majority of variables, the components that create structures were distinguished thanks to the factor analysis.

\section{DISCUSSION}

The analyses allowed to partially confirm the assumed hypotheses. In case of the hypothesis about a lower level of subjective resources in the group of convicts, it may be inferred that it has not been supported to the expected extent, and re- 
search groups are not different in terms of the level of resources to such an extent as it was assumed. Research findings disclosed that the examined groups significantly differentiate between one another only in terms of the self-esteem level and several dimensions of other resources that were subject to research. Self-esteem turned out to be the variable that is significantly lower in case of the convicted persons as compared to the supervised ones, which is proved by previous research. Low self-esteem is treated as a predictor of difficulties with professional stability and delinquency (Campbell, Lavalle, 1993). Self-esteem level is also connected with the maladjustment stage. In its initial stage, the persons committing the prohibited acts usually display lower self-esteem than the persons properly adjusted, and it enhances as a result of autonomisation of the deviant identity (Benda, 2001). Furthermore, the persons serving the penalties for several times undoubtedly present the low level of self-esteem and self-efficacy, and also express the conviction about their helplessness. They perceive themselves in the categories of losers who do not have an influence on external factors and the events that happen in their lives, plus frequently stimulate themselves in the role of the victim of circumstances in which they occur themselves (McNeil, Farrall, Lightowler, et al., 2012). It is worth noticing that a sense of self-efficacy is substantially high in both groups, and in the group of convicts there has been noted its higher level in comparison to the group of the supervised. Any significant intergroup differences have not been noticed. The hypothesis presuming a lower level of the effectiveness in the group of convicts, similarly as of other resources, has not been supported. It is highly likely that the influential factor was represented by too small number of people who have been sentenced multiple times in the group of convicts. Research suggests that a lower level of one's self-efficacy is typical for repeat penitentiary offenders and not for the persons staying in penitentiary isolation for the first time (McNeil, et al., 2012). In the group of the examined convicts a vast majority of them $(89.4 \%)$ has been serving the penalty for the first time and half of them $(51.7 \%)$ declared that it was their first convicting judgement. In the examined group only $7.6 \%$ constituted penitentiary repeat offenders.

Research revealed that the supervised individuals indeed less frequently benefit from the strategy of coping with stress in the form of the use of psychoactive substances. There have not been noticed any significant differences with respect to other strategies. In both groups the persons subject to research gained high scores within the scope of the strategies defined as problem-focused and lower in case of the strategies focused on emotions. It can suggest that the studied persons are good at overcoming difficulties they experience. Significant differences also concerned one of the dimensions of the perceptual social support, i.e. the cognitive support, but an interesting fact is that in the group of convicts its higher level has been noted. It is possible that the persons serving isolation penalties in the penal institution establish such close relationships that they have a feeling of availabil- 
ity of persons with whom they can discuss their problems and, thanks to that, better understand the situation they find themselves in. As for two other dimensions of the support, affiliation and appreciation, a statistical tendency has been noted, which suggests that the examined supervised persons perceive a feeling of bond and closeness with the persons they are important for.

The hypothesis pertaining to positive moderate dependencies between personal resources in both groups has been proved to a large extent, which is consistent with previous research results. Strong and positive correlations between selfefficacy and ego resiliency have been noticed, which could have been expected in the context of high level of both variables (in both groups), also proved by previous research (Niewiadomska, Chwaszcz, 2010). The majority of statistically significant coefficients of correlations were at the moderate level. Positive dependencies between self-esteem and self-efficacy have been noted in both groups (Judge 2009; Warnecke, et al., 2014), and yet the dependencies between self-esteem, selfefficacy and ego resiliency with active stress-coping strategies, which may suggest that the examined persons are good at coping with difficult situations.

In none of the groups the dependencies between the perceptual social support, measured by the ISEL scale, and the rest of the studied resources have been confirmed. Solely moderate positive correlations have been noted among several strategies of coping with stress and its dimensions, i.e. appreciation (PI - shift towards religion; SV - sense of humour, discharge), affiliation ( $\mathrm{SV}$ - positive overvaluation and acceptance) and cognitive support (PI - shift towards religion). Lack of correlations of the ISEL scale with other variables is quite surprising considering the fact that research participants from both groups obtained average scores. Perhaps another tool should be used for studying the perceptual social support that could enable the comparison of the scores. It may also be presumed that evaluation of the perceptual social support has not been adequate because research participants, in particular the convicts, should be characterised by the low level of this variable. The adaptation of the Polish version of the ISEL scale has been conducted among the research group composed of the students and workers (Szlachta 2009), and in its original version - of the students (Cohen, Hoberman, 1983), so there is such a possibility that the convicted individuals, being at different levels of social adjustment, are not an appropriate research group.

The performed analyses were also supplemented by the factor analysis, the aim of which was to determine if the resources create a structure in the groups subject to research. In both research groups the three-factor structure has been obtained, which accounted in total for over $50 \%$ of variances. Its analysis and observed intergroup differences substantiate the need for further research, which could allow for verifying if the distinguished factors and established structures are accurate, and properly describe a set of the subjective resources in research groups. 
The limitation of research consists in conducting it in relatively small groups. It is also worth making comparisons between the group of persons under supervision and those who have been serving the penalties for longer than one year, which would allow for the disclosure of the effects of penitentiary isolation. It would be interesting to incorporate into the research the groups of the convicted and the supervised women and comparing them with account taken of sex. It is also advisable to conduct further research among larger groups, which would allow for verifying the hypothesis about the existence of differences at the level of subjective resources. The carried out research has not revealed such differences in case of the majority of variables, which could suggest that the examined individuals do not significantly differ between one another. It is worth bearing in mind that there are both the persons with penitentiary past as well as those who committed the offense for the first time in both groups. Moreover, research results may be improved through the possibility of repeating research in the broader time perspective, inclusion of quantitative methods and the analysis of social resources, enabling deepened analysis of the observed variables.

\section{REFERENCES}

Bałandynowicz, A. (2016). Kurator jako podmiot integrujący przestrzeń osobową, społeczną i środowiskową w socjalizacji wtórnej osób wchodzących w konflikt z prawem. In: M. Konopczyński, Ł. Kwadrans, K. Stasiak (eds.), Polska kuratela sądowa na przełomie wieków. Nadzieje, oczekiwania, dylematy (pp. 17-48). Kraków: Impuls.

Bandura, A. (2001). Social Cognitive Theory: An agentic perspective. Annual Review of Psychology, 52, 1-26.

Belniak, K. (2014). Poczucie kontroli u sprawców przestępstw agresywnych. Acta Univesitatis Lodiensis. Folia Psychologica, 18, 31-44.

Benda, B. B., (2001). Factors that discriminate between recidivists, parole violators, and nonrecidivists in a 3 - year follow-up of boot camp graduates. International Journal of Offender Theraphy and Comparative Criminology, 45(6), 711-729.

Brezina, T., Topalli, V. (2012). Criminal self-efficacy: Exploring the correlates and consequences of a "Successful Criminal" identity. Criminal Justice and Behavior, 39(8), 1042-1062. DOI: $10.1177 / 0093854812438345$

Campbell, J. D., Lavalle, L. F. (1993). Who Am I? The Role of Self-Concept Confusion in Understanding the Behavior of People with Low Self-Esteem. In: R. F. Baumaister (ed.), Self-Esteem. The Puzzle of Low Self-Regard (pp. 3-20). New York - London: Springer.

Cohen, S., Hoberman, H. M. (1983). Positive Events and Social Support as Buffers of Life Change Stress. Journal of Applied Social Psychology, 13 (2), 99-125.

Dudek, B., Koniarek, J. (2003). Wsparcie społeczne jako modyfikator procesu stresu - wybrane problemy teoretyczne i narzędzie pomiaru. Medycyna Pracy, 54 (5), 427-435.

Fidelus, A. (2012). Determinanty readaptacji społecznej skazanych. Warszawa: Wydawnictwo Uniwersytetu Kardynała Stefana Wyszyńskiego.

Fredrickson, B. L., Tugade, M. M., Waugh, C. E., Larkin, G. R. (2003). What Good Are Positive Emotions in Crises? A Prospective Study of Resilience and Emotions Following the Terrorist Attacks on the United States on September $11^{\text {th }}$. Journal of Personality and Social Psy- 
chology, 84(2), 365-376. Retrieved May 2, 2019, from https://ncbi.nlm.nih.gov/pmc/articles/ PMC2755263

Heszen-Niejodek, I. (2000). Stres i radzenie sobie - główne kontrowersje. In: I. Heszen-Niejodek, Z. Ratajczak (eds.), Człowiek w sytuacji stresu. Problemy teoretyczne i metodologiczne. Katowice: Wydawnictwo Uniwersytetu Śląskiego.

Hobfoll, S. E. (2006). Stres, kultura i społeczność, Psychologia i filozofia stresu. Gdańsk: Gdańskie Wydawnictwo Psychologiczne.

Huflejt-Łukasik, M. (2010). Ja i procesy samoregulacji. Różnice między zdrowiem a zaburzeniami psychicznymi. Warszawa: Wydawnictwo Scholar.

Jaworska, A. (2016). Zasoby osobiste $i$ społeczne skazanych $w$ procesie oddziatywań penitencjarnych. Kraków: Impuls.

Juczyński, Z. (2000). Poczucie własnej skuteczności - teoria i pomiar. Acta Universitatis Lodziensis. Folia Psychologica 4, 11-24.

Juczyński, Z. (2009). Pomnażanie i wzbogacanie zasobów własnego zdrowia. Polskie Forum Psychologiczne, 1, 17-32.

Judge, Th. A. (2009). Core Self_Evaluation and Work Success. Current Directions in Psychological Science, 18(1), 58-62.

Kaczmarek,Ł.,Sęk,H.,Ziarko,M.(2011).Sprężystośćpsychicznaizmiennepośredniczącewjejwpływie na zdrowie. Przeglad Psychologiczny, 54(1), 29-46. Retrieved February 5, 2019, from https:// researchgate.net/publication/216100640_Sprezystosc_psychiczna_i_zmienne_posredniczace _w_jej_wplywie_na_zdrowie_Ego_Resiliency_and_the_mediators_of_its_effect

Kieszkowska, A. (2012). Inkluzyjno-katalaktyczny model reintegracji społecznej skazanych. Konteksty resocjalizacyjne. Kraków: Impuls.

Kościelak, R. (2010). Poczucie umiejscowienia kontroli i przekonania o własnej skuteczności w zdrowiu i chorobie. Kraków: Impuls.

Kwadrans, Ł., Konaszewski, K., (2017). Prężność psychiczna a wsparcie społeczne w grupie młodzieży nieprzystosowanej społecznie. Badania pilotażowe, Resocjalizacja Polska, 13, 163-173.

Landis, B. D, Altman, J. D., Cavin, J. D. (2007). Underpinnings of Academic Success: Effective Study Skills Use as a Function of Academic Locus of Control and Self-Efficacy. Journal of Undergraduate Research, 12(5), 126-130.

Letzring, T. D., Block, J., Funder, D. C. (2005). Ego-control and ego-resiliency: Generalization of self-report scales based on personality descriptions from acquaintances, clinicians, and the self. Journal of Research in Personality, 39(4), 395-422. DOI: 10.1016/j.jrp.2004.06.003.

Łaguna, M. (2015). Zasoby osobiste jako potencjał w realizacji celów, Polskie Forum Psychologiczne, 20(1), 5-15.

Łaguna, M., Lachowicz-Tabaczek, K., Dzwonkowska, I., (2007). Skala samooceny SES Morrisa Rosenberga - polska adaptacja metody, Psychologia Spoteczna, 2,164-176.

Machel, H. (2003). Więzienie jako instytucja karna i resocjalizacyjna, Gdańsk: Wydawnictwo Arche.

Maschi, T. (2007). Trauma and Violent Delinquent Behavior among Males: The Moderating Role of Social Support. Stress, Trauma, and Crisis An International Journal, 9(1), 45-72. DOI: $10.1080 / 15434610500506233$

McNeil, F., Farrall, S., Lightowler, C., Maruna, S. (2012). How and why people top offending: discovering desistance. Glasgow: Institute for Research and Innovation in Social Services, University of Glasgow.

Niewiadomska, I. (2010). Znaczenie zasobów psychospołecznych w procesie resocjalizacji. In: L. Pytka, B. M. Nowak (eds.), Problemy wspótczesnej resocjalizacji (pp. 57-66). Warszawa: Wydawnictwo Pedagogium. 
Niewiadomska, I., Chwaszcz, J. (2010). Jak skutecznie zapobiegać karierze przestępczej?. Lublin: Fundacja Rozwoju KUL.

Ogińska-Bulik, N. (2008). Zasoby osobiste w radzeniu sobie ze stresem, Zeszyty Naukowe WSHE, 13, 93-103.

Ogińska-Bulik, N., Juczyński, Z. (2009). Inwentarz do pomiaru radzenia sobie ze stresem. Warszawa: Pracownia Testów Psychologicznych PTP.

Ostrihanska, Z. (1978). Problemy nieprzystosowania społecznego u dzieci i młodzieży. In: Jasiński J. (ed.), Zagadnienia nieprzystosowania społecznego i przestępczości w Polsce, Wrocław, Warszawa, Kraków, Gdańsk: Ossolineum.

Puskar, K., Bernardo, L. M., Haley, T. M., Tark, K. H., Switala, J., Siemion, L. (2010). Self-Esteem and Optimism in Rural Youth: Gender Differences. Contemporary Nurse, 34(2), 190-198.

Seiffge-Krenke, I. (2000). Causal links between stressful events, coping style, and adolescent symptomatology. Journal of Adolescence, 23(6), 675-691. DOI: 10.1006/jado.2000.0352

Steuden, S., Jaworowska, K. (2004). Egzystencjalny wymiar doświadczania izolacji więziennej przez osoby skazane na karę pozbawienia wolności. In: M. Kuć, I. Niewiadomska (eds.), Kara kryminalna. Analiza psychologiczno-prawna (pp. 291-315). Lublin: Towarzystwo Naukowe KUL.

Szlachta, E. (2009). Próba adaptacji i walidacji polskiej wersji The Interpersonal Support Evaluation List - ISEL, Kwestionariusz Spostrzeganego Wsparcia Społecznego. Przeglad Psychologiczny, 52(4), 433-451.

Terelak, J. F. (2008). Człowiek i stres. Warszawa - Bydgoszcz: Branta.

Tomczak, K. (2009). Style radzenia sobie w sytuacji stresowej, przekonanie o własnej skuteczności, nadzieja na sukces u studentów rozpoczynających i kończących studia, Psychoterapia, 2(149), $67-79$.

Warnecke, A. J., Baum, C. B., Peer, J. R., Goreczny, A. J. (2014). Intercorrelations between Individual Personality Factors and Anxiety. College Student Journal, 48(1), 23-33.

Wysocka, E., Ostafińska-Molik, B. (2014). Wybrane determinanty polaryzacji samooceny w grupie wychowanków Młodzieżowych Ośrodków Wychowawczych i Socjoterapeutycznych, Resocjalizacja Polska, 12, 119-144.

\section{STRESZCZENIE}

Celem artykułu jest porównanie zasobów osobistych skazanych odbywających kary w izolacji penitencjarnej oraz pozostających pod dozorem kuratorów sądowych. Przy pomocy testów mierzących poczucie własnej skuteczności, samoocenę, radzenie sobie ze stresem, spostrzegane wsparcie społeczne i sprężystość psychiczną przebadano 66 osadzonych i 68 dozorowanych. Wbrew oczekiwaniom skazani charakteryzowali się dość wysokim poziomem większości badanych zasobów. Jednocześnie obie grupy okazały się być do siebie na tyle podobne, że istotne statystycznie różnice ujawniły się tylko w zakresie poziomu samooceny, wsparcia poznawczego i strategii radzenia sobie ze stresem w postaci zażywania substancji psychoaktywnych. Potwierdzono istnienie pozytywnych zależności między badanymi zmiennymi, a dla uzupełnienia analiz zbadano strukturę zasobów podmiotowych w obu grupach. Przedstawiono też ograniczenia i kierunki dalszych badań.

Słowa kluczowe: wsparcie społeczne; samoocena; poczucie własnej skuteczności; sprężystość psychiczna; radzenie sobie ze stresem; przestępczość; zasoby osobiste 